\title{
Biotech aspects of Caridean shrimp cultivation
}

\author{
Lina Lagutkina ${ }^{1, *}$, Alexander Nevalennyy ${ }^{1}$, Aliya Akhmedzhanova ${ }^{1}$, Sergey Ponomarev ${ }^{1}$, \\ and Yulia Fedorovykh ${ }^{1}$ \\ ${ }^{1}$ Astrakhan state technical University, 16, Tatishchev Str., 414056, Astrakhan, Russia
}

\begin{abstract}
Mariculture is the direction of aquaculture associated with the cultivation of marine hydrobionts as fish and other aquatic organisms and plants. Although it produces only $13 \%$ of the world's fish and other seafood products, this industry is characterized by a high rate of development (6-7\% annual growth), which is now the highest among all branches of the world's food industry. Industry performance depends on the industrial implementation of best practices in manufacturing countries. The successful practice of industrial cultivation will be promoted by timely modernization of the technological process. In this regard, the problems of aquaculture practice and the use of technical means in the field of mariculture, considered in this article, are particularly relevant. The authors describe the biotechnological aspects of growing caridean shrimp. As a result of the experimental work carried out by scientists of the Astrakhan state technical University, the conditions for growing caridean shrimp in the South of Russia were adapted and biotechnical standards for obtaining commercial products were developed. Feed own recipes for caridean shrimp were developed. Morphophysiological parameters of caridean shrimp were studied.
\end{abstract}

\section{Introduction}

In contrast to fisheries, which are constrained by biological and environmental constraints, the global aquaculture sector (marine and freshwater) continues to grow steadily. Thus, according to the Food and agriculture organization of the United Nations (FAO), in the period from 2011 to 2016, the annual growth of total aquaculture production (excluding aquatic plants) was 5.8 percent, reaching an estimated total production of 80 million tons [1].

Fish plays a crucial role in ensuring the food security of the world's population - it accounts for about 20 percent of animal protein and 6.7 percent of all protein consumed by mankind. This level is even higher in some developing regions (Indonesia, Sri Lanka, etc.) and, in particular, in numerous island developing countries, which receive about half of the volume of animal protein from water products. As the World's population grows and average incomes grow, the demand for ocean food will continue to increase. According to the FAO forecast, in order to feed the world's population in 2050, an additional 20 million metric tons of protein will be required, and, according to industry experts, food from the sea will be able to cover most of this need [2]. However, let us clarify that in this case we are

\footnotetext{
${ }^{*}$ Corresponding author: lagutkina_lina@mail.ru
} 
talking about the potential for expanding aquaculture (including mariculture), but not fishing.

Global mariculture produced 29 million tons of aquatic organisms in 2016, which is more than one-third of the total production of fish aquaculture and about a quarter of the total production of marine fish [3].

More than half of the mariculture production of marine organisms is shellfish. Fish and crustaceans account for $23 \%$ and $17 \%$ of production.

Mariculture, like freshwater aquaculture, is divided into two areas: production without growing feed (algae, filter shellfish) and production using feed (fish, crustaceans and gastropods).

There are significant differences in the current state and prospects for the development of these areas. Mariculture with feeding requires the use of aquaculture compound feeds with a certain content of protein, fat, carbohydrates, minerals and vitamins to ensure a sustainable production process, and the growth of aquatic organisms (fish, shrimp, etc.). Whereas mariculture without feeding (seaweed, bivalves) does not need industrial feed, independently extracting nutrients from the environment (for example, phytoplankton) [4].

The development of the first of these areas is more promising from the point of view of obtaining valuable food products and is stimulated by the leading demand, but has limitations in the form of the need for feed. The development of mariculture without feeding consists in the possibility of producing mainly low-value organisms, and is also constrained by environmental factors of the local environment's food supply, which is under pressure from the effects of climate change everywhere.

Aquaculture is the fastest growing sector of food production, and industrial shrimp farming is one of the notable production areas. Thus, the volume of aquaculture shrimp is already higher than the volume of its production by fishing [5]. So, in 2016, fishermen produced 3500 thousand tons of shrimp in the world, while aquaculture produced 5364 thousand tons, including: in the mariculture of white - legged shrimp (Penaeus vannamei) - 4156 thousand tons and giant tiger shrimp (Penaeus monodon) - 701 thousand tons, in freshwater aquaculture, freshwater eastern shrimp (Macrobrachium nipponense) - 273 thousand tons and freshwater giant shrimp (Macrobrachium rosenbergii) - 234 thousand tons [6].

However, both wild and aquaculture shrimp production in the natural environment (cages, ponds) remain very vulnerable. Thus, the viral epidemics of the mid -1990s and the bacterial epidemic of 2009-2015 caused significant damage to aquaculture farmers and producers. Thus, the branch of fisheries science faced a challenge, since it became obvious that sustainable development of the field is not possible without more effective biological, environmental, genetic technologies, as well as the cultivation and selection of more resistant species.

Shrimp production is a promising, economically attractive area of industrial aquaculture. The capacity of the Russian market for shrimp consumption in natural terms exceeds 40 thousand tons. This product is mainly represented by imported frozen products: 9.4 thousand tons are exported from India, 7.8 thousand tons from Grenland, and 7.2 thousand tons from China. The main limiting factor in the development of shrimp production in Russia is the lack of biotechnological standards and proprietary feed for production $[5,6]$. The purpose of our study was to develop biotechnological aspects of the issue of growing caridean shrimp. The technologies presented below will help fill the gap in the special methodological framework for the systematic introduction of specialized farms for growing shrimp [7-16]. 


\section{Materials and methods}

Experimental work was carried out on the basis of the Innovation center "Bioaquapark-STC of aquaculture" of the Astrakhan state technical University and Modern Sharapovskiy Fish Breeding Complex. The object of the study was larvaee, juveniles, and shrimp breeders. As a result of the experimental work carried out by scientists of the Astrakhan state technical University, the conditions for growing caridean shrimp in the South of Russia were adapted and biotechnical standards for obtaining commercial products were developed.

In many years of work on the development of biostandards, methods were used: production of experimental feeds in laboratory conditions using domestic feed components by wet pressing at low pressure according to the recipes of production feeds, estimation of nutritional value. When assessing the effect of feed on the status of grown shrimps, a set of fish-biological and physiological-biochemical methods was used [8-16] (figure 1).

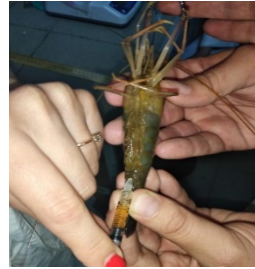

a

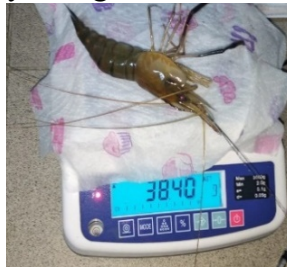

b

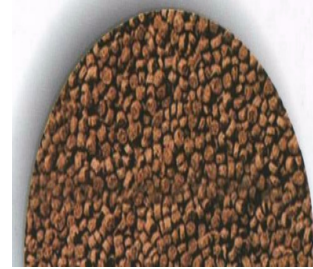

$\mathrm{c}$

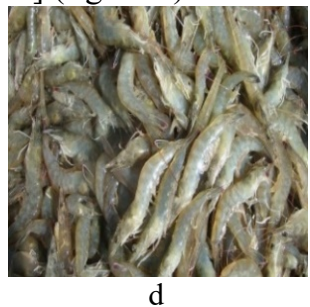

Fig. 1. a - assessment of morphophysiological indicators, $b$ - control weighing, $c$ - sample of feed, $d$ - commodity products.

The oxygen content in the water was determined daily three times a day (to prevent unwanted fluctuations) using a "CyberScanDo 300" thermo-oximeter. PH values were determined using the "Hanna" pH meter. In addition, the water temperature was recorded 3 times a day. All data was subjected to statistical processing using the Excel stat analysis software panel. At the same time, we used elements of statistical analysis to determine the mean observation and probable error. The level of differences was evaluated using the student's confidence criterion.

\section{Discussion of the results}

\subsection{Caridean shrimp breeding}

The biotechnology of caridean shrimp breeding includes the following stages, which have their own peculiarities as distinct from the stages of penaeid shrimp breeding:

- producers keeping;

- larvae hatching;

- larvae breeding up to juvenile stage;

- young shrimp breeding up to marketable dimensions;

- one-year young shrimp breeding up to the weight of 60 grams;

- two-year young shrimp breeding up to the commercial weight of 150 grams.

In the biotechnological process of shrimp breeding, it is necessary to take into consideration: the terms and the period of egg release to female shrimp pleopods; fertility and duration of hatching period (from the moment of eggs release to female shrimp pleopods and up to embryos hatching); amount of egg losses within this period; intensity and frequency of larvae hatching; terms and duration of their molts; transition to independent feeding; and the specifics of the cultivation environment for various stages of larvae metamorphosis and producers' maturation. 
Macrobrachium rosenbergii are bred in countries located in South-East Asia, Latin America, and the USA [8-10], though their breeding is aggravated due to males' aggressiveness, high requirements to the amount of water, gas and temperature regimes. In the southern regions of Russia, caridean shrimps are grown in ponds using alternate cultivation of aquacultural and agricultural products, feeding, polyculture, and closed water supply systems.

\subsubsection{Caridean shrimp breeding}

Breeding starts with the selection of producers. An aquarium or a tray with a 60-liter capacity is sufficient for one couple of producers. Mature males are kept separately from females and from each other - one per aquarium; it is not recommended to keep them together since there is a possibility of cannibalism during molting periods. This is why it is necessary to move the molting males to individual aquariums for 2-3 hours (until their chitinous shells stiffen). The females, which have recently molted, are placed in the aquarium with a male, where within 24 hours mating and eggs fertilization take place. The females with eggs are kept separately in spawning aquariums of 50-60 liter capacity. Macrobrachium rosenbergii, or giant prawn, females with ripe eggs are kept at a temperature of $28-30^{\circ} \mathrm{C}, \mathrm{pH} 7.5-8.0$ and salinity of 7-8 ppt until larvae hatching. According to some other data, salinity should be equal to $12 \mathrm{ppt}$ during the last stage of egg incubation [11]. The eggs remain attached to the female and develop within 19 days at a temperature of $26-28^{\circ} \mathrm{C}$. On the twelfth day of the development, the color of the eggs changes from orange to straw-colored. Then, the eggs become grey (steel shaded). After that, larvae hatching begins.

\subsubsection{Hatching}

During egg development, water in the spawning aquarium should be aerated. As soon as the color of eggs changes from orange to grey, $5 \%$ of the sea water is added to the aquarium to bring the salinity up to $12 \mathrm{ppt}$, which helps make the hatching of larvae easier. To breed them, tanks with a dimension of $0.5 \times 0.7 \times 2-3 \mathrm{~m}$ are used, with a slight bottom slope towards the drain, or tanks with closed water recirculation system. The optimal water temperature is equal to $26-28^{\circ} \mathrm{C}, \mathrm{pH}-7-8$, salinity $-12-14$ ppt. The water is constantly aerated and partially changed every ten days. Water should not contain chlorine.

\subsubsection{Larvae and maintaining young fish}

Larvae are hatched at the zoeae stage, and at the stage of myses they are juvenile shrimp, which look like adult shrimp. The hatched larvae are kept at a temperature of $28-30^{\circ} \mathrm{C}$, and a water salinity of 12-14 ppt. As the young shrimp are growing, water salinity is reduced and brought down to $2 \mathrm{ppt}$, i.e. its breeding is continued in low-salted or fresh water.

Larvae are often sick with fungus diseases. A good remedy against diseases is a sixhour larvae treatment with a solution of malachite green $(0.2 \mathrm{mg} / \mathrm{l})$. Cannibalism occurs among growing shrimp; this is why a significant amount of well-balanced feeds is required in the breeding process. Permanent monitoring of the breeding environment quality and application of preventive measures against diseases are necessary.

They start feeding Macrobrachium rosenbergii larvae when they are 2-3 days old. During the first two weeks, they are fed three times a day and once at night. In the following period the feeds are given four times during the day time and once at night. They are fed with plankton crustaceans or Artemia nauplii. One teaspoon of decapsulated eggs of Artemia per 60 thousand larvae is given every day during the first 3-4 days, and during the 
following 30 days of breeding 1.5 teaspoons of Artemia eggs are fed. The meat of the fish or crustaceans, boiled mashed eggs, eggs pate and eggs of trash fish can serve as a feed for larvae. The eggs of trash fish is freed from membrane and washed in clean water several times. Then, small eggs are fed to the younger age groups of larvae, and large eggs are to elder age groups of larvae. The day ratio is about $30 \%$ of the weight of larvae.

\subsubsection{Post-larvaee and juveniles breeding}

After the major part of larvae reaches the stage of metamorphosis, they are transferred to the ponds. Prior to transferring, larvae acclimatize to the fresh water for 6-8 hours.

They leave the bottom of the ponds silty and construct cement walls. The ponds are continuously supplied with circulating and aerated water. On the bottom, along the pond walls, they lay branches, gravel and shellfish shells where post-larvae hide after molting. Usually about 10 thousand post-larvae are bred in one pond with a dimension of $5 \times 10 \times 0.4$ meters. Post - larvae consume small oligochaetes, chironomides, set food and fouling, so in ponds set submersible bags with hay at least 25 PCs. One-day post-larvae are fed 2 times dry food, and at night-live or chilled minced meat. If vegetative feeds are available, they are given once in 2 days. In two months, the larvae grow up to $5 \mathrm{~cm}$ in length and are ready to be transferred to big nursery ponds.

Drying of the pond's bed and its disinfecting before and after use prevent infectious and parasitic diseases in shrimp. To breed commercial long arm shrimp ponds, they use open pits and irrigations channels with a total area of 400 square meters and depth $-30 \mathrm{~cm}$, as well as ponds with an area of 1000 square meters and a depth of 1-1.5 square meters.

Water inlet and water outlet constructions are equipped with nets to protect shrimp against carnivores. Water in the reservoirs, where shrimp are bred, should be constantly replaced.

For the development of phytoplankton, zooplankton and benthos, the addition of reservoir organic fertilizers (200 $\mathrm{kg}$ of cow dung per ha) and lime (10 $\mathrm{kg}$ per ha) each month is recommended.

Animal feeds are used to feed shrimp in case of shrimp commercial breeding in large nursery ponds. These are trash fish meat, shell-fish, earthworms, meat and fish wastes, insects, silkworm chrysalis. Vegetable feeds are also used (ground rice and fruit wastes). 75 percent of the daily dietary intake consists of artificial feed, and 25 percent consists of natural feeds. The daily dietary intake equals 50 percent of the total weight of shrimp. One half of the daily dietary intake is given in the morning, and the other half is given in the afternoon. The feeds are placed in feed cribs, and the feed cribs are placed along both sides of the pond. For molting shrimps, shelters made of branches, tiles and shells are constructed in shallow spots.

Shrimp are sensitive to a lack of oxygen dissolved in water. For this reason, it is necessary to define oxygen content in water on a regular basis. In optimal breeding conditions, young shrimp which are $5 \mathrm{~cm}$ long and weigh 1-2 grams gain 100 grams in $5-$ 6 months, which allows two harvests under tropical conditions. Shrimp of commercial size can be grown in rice checks.

Shrimp of the adspersus and the elegans species live in the Black and the Azov seas. They are characterized by a two-year biological cycle. Shrimp reach a length of 5-8 $\mathrm{cm}$ and a weight of 1.5-2 grams. They are euryhaline and eurythermal, and they easily sustain seasonal changes in temperatures from $0^{\circ} \mathrm{C}$ and $30^{\circ} \mathrm{C}$ and salinity from 3 to 30 ppt. They lay eggs 3-4 times per summer at a temperature of $15-20^{\circ} \mathrm{C}$ and a salinity of $9-25 \mathrm{ppt}$. At the lower salinity, shrimp's active osmotic regulation is changed into passive, and they become inviable. At a temperature of $0.5^{\circ} \mathrm{C}$ shrimp is motionless, they do not eat, and their need in oxygen reduces to $0.05-0.07 \mathrm{mlg} / \mathrm{h}$. Respiration intensity and feed consumption 
increase when the water temperature raises from 9 to $25^{\circ} \mathrm{C}$. At a temperature of $19-22^{\circ} \mathrm{C}$, shrimp consume oxygen in the amount of $0.32 \mathrm{mlg} / \mathrm{h}$, and their daily food consumption equals 16 percent of their body mass. At a temperature $27-30^{\circ} \mathrm{C}$, a distortion of physiological processes exhibits very obviously. First, there is a sharp increment in activity (oxygen consumption raises up to $0.47-0.5 \mathrm{mlg} / \mathrm{h}$ ), feeding stops, and then shrimp dies at a temperature of $30-32^{\circ} \mathrm{C}$. The content of oxygen in water below $40 \%$ saturation is of crucial importance.

Coldwater shrimp, which live in coastal waters of the Far East, are of a great interest for cultivation in our country. The most valuable species of coldwater shrimp is pacific grass shrimp. This is a typical marine shrimp with a length up to $13 \mathrm{~cm}$ and a weight of up to 16 grams. It can sustain salinity from 11 to $50 \mathrm{ppt}$, but it reproduces at a salinity of 24-34 ppt. The range of changes in the temperature of water, where the shrimp can keep viable for a while, is especially broad. Thus, at a gradual reduction of the water temperature to minus $2.5^{\circ} \mathrm{C}$, the shrimp become inactive. In the range of temperatures between 10 and $23^{\circ} \mathrm{C}$, physiological processes go normally. At water temperature of $18-23^{\circ} \mathrm{C}$ and salinity of $24-$ $35 \mathrm{ppt}$, shrimp feeds well; shrimp also grow and develop quickly at this temperature, reaching sexual maturity by 6-12 months. These shrimp are very sensitive to a lack of oxygen; at a water temperature of $16-17^{\circ} \mathrm{C}$ saturation with oxygen in the amount of $47-42 \%$ is of crucial importance, and $21 \%$ is the threshold amount. If adult producers are kept in nurseries and young shrimp are grown in salted lagoons or tanks, then in one summer and one winter shrimp will gain a commercial weight of 5-8 grams.

\subsection{Giant shrimp cultivation}

When cultivating giant shrimp in the systems where intensive methods of breeding are used, the following stages can be identified:

- producers seasoning and spawning;

- $\quad$ eggs hatching and acquiring of larvae (October - May);

- larvae breeding in a closed system in nursery ponds with a sea water salinity of $7-8$ ppt and a temperature of $28-30^{\circ} \mathrm{C}$ (May - February);

- post-larvae breeding in a closed system of nursery reservoirs up to the stage of young shrimp with a weight of 2.9 grams with stocking density equal to 500 pcs per square meter (mid-February - May);

- shrimp-breeding in ponds up to commercial size (May - mid-October). Ponds productivity amounts to $1-1.5$ tons per hectare.

Giant shrimp are bred in ponds in summer, and the water temperature is $28-30^{\circ} \mathrm{C}$. Such a breeding of young shrimp in reservoirs with fresh water is possible in mono - and polyculture with planktivorous and phytovorous fish. These are: bighead, silver carp, gourami, tilapia and Chinese carp. In salt water, it is possible to breed them together with grey mullets. According to L. Yu. Lagutkina and S. V. Ponomarev, the biotechnology of giant shrimp cultivation includes stages that meet the following standards (table 1).

Table 1. Biotechnological standards for growing caridean shrimps in the South of Russia.

\begin{tabular}{|l|c|}
\hline \multicolumn{1}{|c|}{ Stages } & Normative Standards \\
\hline \multicolumn{1}{|c|}{ Spawning reservoirs } \\
\hline Average weight of producers, gram & $40-60$ \\
\hline «Male:female» ratio & $1: 3-4$ \\
\hline $\begin{array}{l}\text { Stocking density in closed recirculation pool system (CRPS), } \\
\text { fish per square meter }\end{array}$ & $\leq 5-6$ \\
\hline A female fecundity, thousand eggs & 45 \\
\hline Larvae yield, \% & 85 \\
\hline Larvae released by a female, thousand larvae & $35-40$ \\
\hline
\end{tabular}




\begin{tabular}{|c|c|c|}
\hline \multicolumn{3}{|c|}{ Larvae breeding } \\
\hline Stocking density, pes per liter & \multicolumn{2}{|c|}{$\leq 30$} \\
\hline Post-larvae yield, $\%$ & \multicolumn{2}{|c|}{45} \\
\hline \multicolumn{3}{|c|}{ Larvae growing in CRPS } \\
\hline Post-larvae stocking density, pcs per square meter & \multicolumn{2}{|c|}{$2000-3000$} \\
\hline $\begin{array}{c}\text { Young shrimp stocking density: } \\
\text { aged } 30 \text { days } \\
\text { aged } 60 \text { days } \\
\text { aged } 90 \text { days }\end{array}$ & \multicolumn{2}{|c|}{$\begin{array}{c}1000-15000 \\
500-600 \\
250-300\end{array}$} \\
\hline Survival rate, $\%$ & \multicolumn{2}{|c|}{90} \\
\hline \multicolumn{3}{|c|}{ Commercial cultivation in ponds in monoculture } \\
\hline Area, ha & \multicolumn{2}{|c|}{$0.5-0.75-1.0$} \\
\hline Water temperature, $\mathrm{t},{ }^{\circ} \mathrm{C}$ & \multicolumn{2}{|c|}{$24-27$} \\
\hline $\begin{array}{l}\text { Oxygen, } \mathrm{O}_{2} \\
\text { water delivery } \\
\text { coastal zone } \\
\text { water intake (monach system) }\end{array}$ & \multicolumn{2}{|c|}{$\begin{array}{l}6.5 \\
5.3 \\
4.8\end{array}$} \\
\hline Oxygen content, $\mathrm{mg} / \mathrm{l}$ & \multicolumn{2}{|c|}{7.0} \\
\hline Transparency, cm & \multicolumn{2}{|c|}{31} \\
\hline Hydrogen ion exponent $(\mathrm{pH})$ & \multicolumn{2}{|c|}{$7.0-7.3$} \\
\hline Organic matter in bottom sediments, humus content, $\%$ & \multicolumn{2}{|c|}{$0.5-3.8$} \\
\hline Zooplancton, $\mathrm{B} \mathrm{g} / \mathrm{m}^{3}$ & \multicolumn{2}{|c|}{$>3.0$} \\
\hline Zoobenthos, B g/m² & \multicolumn{2}{|c|}{$<4$} \\
\hline $\begin{array}{l}\text { Stocking density of juveniles, thousand pieces/ha } \\
\text { without feeding } \\
\text { with feeding }\end{array}$ & \multicolumn{2}{|c|}{$\begin{array}{c}6.0 \\
15\end{array}$} \\
\hline Survival rate, $\%$ & \multicolumn{2}{|c|}{90} \\
\hline $\begin{array}{l}\text { Bioproductivity, c/ha } \\
\text { without feeding } \\
\text { with feeding }\end{array}$ & \multicolumn{2}{|c|}{$\begin{array}{c}5.0 \\
10.0\end{array}$} \\
\hline Feeding rate, times/day & \multicolumn{2}{|c|}{1} \\
\hline Additional feeding & \multicolumn{2}{|c|}{1} \\
\hline Yield, kg/ha & \multicolumn{2}{|c|}{$500 / 1300$} \\
\hline Average weight, $g$ & \multicolumn{2}{|c|}{$40-80$} \\
\hline \multicolumn{3}{|c|}{ Commercial breeding in ponds in polyculture } \\
\hline Stocking density, thousand pcs per hectare & \multicolumn{2}{|c|}{$5-20$} \\
\hline Survival rate, $\%$ & \multicolumn{2}{|c|}{90} \\
\hline Product yield, kilogram per hectare & \multicolumn{2}{|c|}{$135-360$} \\
\hline Average weight of one piece, gram & \multicolumn{2}{|c|}{$20-30$} \\
\hline Stocking density, thousand fishes per hectare & fingerlings & $\begin{array}{l}\text { two-year old } \\
\text { fish }\end{array}$ \\
\hline $\begin{array}{l}\text { paddle fish } \\
\text { carp } \\
\text { silver carp } \\
\text { silver carp hybrids or bighead } \\
\text { grass carp }\end{array}$ & $\begin{array}{c}2.5-3 \\
65 \\
50 \\
10 \\
5\end{array}$ & $\begin{array}{c}- \\
3800 \\
1050 \\
700 \\
150\end{array}$ \\
\hline
\end{tabular}

When growing adult shrimps, artificial food must be used. The results of growing shrimp depend largely on the quality of feed. Shrimp need food with protein content in the feed mixture of about 40-60 \%. Squid meat, soy flour, shrimp flour, and some types of fish 
meal are suitable sources of protein. The composition of feed proteins must meet the needs of shrimp in essential amino acids: phenylalanine, lysine, histidine, aspartic acid, threonine, valine, methionine, isoleucine, leucine and tryptophan.

For shrimps, the presence of essential fatty acids in the feed is necessary. The presence of linolenic acids is very important. The effectiveness of using carbohydrates depends on their source. So, starch is absorbed by shrimp much better than simple carbohydrates. In the feed mixture, the presence of about $0.5 \%$ sterols is necessary, since shrimp do not synthesize them, but their high content in the feed leads, in particular, to a delay in the growth of shrimp. Be sure to have vitamins, mineral components and trace elements in the feed. Streptocephalus can be used as a live food for shrimp in the early stages of development in the absence of Artemia. The organization of feeding should be carried out in accordance with the guidelines for the methods of diet and feeding technology presented in tables 2.3 .

Table 2. Feed of own recipes for caridean shrimp.

\begin{tabular}{|c|c|c|}
\hline Components & Dry feed & Chilled feed \\
\hline \multicolumn{3}{|c|}{ Components of animal origin } \\
\hline bloodworm & + & - \\
\hline shrimp, crayfish & + & - \\
\hline streptocephalus & + & - \\
\hline fish meal & + & + \\
\hline not valuable fish & & + \\
\hline \multicolumn{3}{|l|}{ Components of plant origin } \\
\hline Laminaria & + & - \\
\hline Ponds' biomass & + & - \\
\hline wheat flour & + & + \\
\hline rolled oats & - & + \\
\hline rice & - & + \\
\hline carrot & + & + \\
\hline pumpkin & - & + \\
\hline wetgrass & + & - \\
\hline oak leaves & + & - \\
\hline \multicolumn{3}{|c|}{ Minerals and vitamin supplements } \\
\hline Calcium supplement & + & - \\
\hline Vitamin C & + & - \\
\hline \multicolumn{3}{|l|}{ Fat supplements } \\
\hline Fish oil & + & - \\
\hline Vitamin E & + & - \\
\hline \multicolumn{3}{|l|}{ Composition } \\
\hline crude protein, $\%$ & 40 & 30 \\
\hline fat, $\%$ & 8 & 5 \\
\hline fiber, $\%$ & 6 & 6 \\
\hline ash, $\%$ & 13 & 13 \\
\hline calcium, $\%$ & 3 & 3 \\
\hline phosphor, \% & 0.7 & 0.7 \\
\hline
\end{tabular}

The formula and nutritional properties of compound feed are presented in table 2; feed indicators are presented in table 3 . 
Table 3. The indices of the start and production feeds.

\begin{tabular}{|c|c|c|c|c|c|}
\hline Feed & $\begin{array}{c}\text { Protein, } \\
\mathbf{\%}\end{array}$ & $\begin{array}{c}\text { Weight, } \\
\mathbf{g}\end{array}$ & $\begin{array}{c}\text { Pellets size } \times \\
\text { diameter, } \\
\mathbf{m m}\end{array}$ & Pellet, g & $\begin{array}{c}\text { Productivity, } \\
\text { kg/ha (yield *) }\end{array}$ \\
\hline \multicolumn{6}{|c|}{ Start feeds } \\
\hline Start & 40 & $3-6$ & $2,0 \times 2,0$ & 80 & stocking \\
\hline \multicolumn{6}{|c|}{ Ponds } \\
\hline Product (wet feed) & $25-35$ & $\begin{array}{c}\text { More } \\
\text { then } 6\end{array}$ & $2,5 \times 7$ & 30 & 5,000 \\
\hline \multicolumn{6}{|c|}{ Tanks } \\
\hline $\begin{array}{c}\text { Product } \\
\text { (dry feed) }\end{array}$ & 35 & $\begin{array}{c}\text { More } \\
\text { then } 6\end{array}$ & $2,0 \times 4$ & 50 & 12,000 \\
\hline Product & 40 & $\begin{array}{c}\text { More } \\
\text { then } 6\end{array}$ & $2,5 \times 7$ & 30 & $12,000 *$ \\
\hline Product & 40 & $\begin{array}{c}\text { More } \\
\text { then } 6\end{array}$ & $2,0 \times 4$ & 50 & more then 13,000 \\
\hline
\end{tabular}

The components used in the feeds are their own achievement. The appropriate size of the feed particles provides better nutrition during the first stages of shrimp development, hence high survival rates and a fast growth rate. Feeds are specially developed for shrimp and are presented in several types with different composition and energy value.

It is necessary to pay attention to the last stage of shrimp cultivation: if it is growing in a pond, then shrimp fishing should take place earlier than fishing, at a water temperature not lower than $19^{\circ} \mathrm{C}$.For shrimp fishing, traps such as crustaceans' traps or nets can be used.

For transfer to artificial conditions and further production of offspring, physiologically healthy individuals are selected according to the data presented in table 4.

Table 4. Morphophysiological standards of caridean shrimp.

\begin{tabular}{|l|c|c|}
\hline \multicolumn{1}{|c|}{ Indices } & Ponds & Tanks \\
\hline \multicolumn{3}{|c|}{ Piscicultural } \\
\hline Initial weight, g & 5 & 30 \\
\hline Final weight, g & 90 & 150 \\
\hline Absolute growth rate, g & 85 & 120 \\
\hline Period, days & 120 & 200 \\
\hline \multicolumn{2}{|c|}{ Physiological and biochemical } \\
\hline Total protein, g/l & $50.29 \pm 4.7$ & $36.1 \pm 5.6$ \\
\hline Cholesterol, mmol / 1 & $5.04 \pm 0.2$ & $4.3 \pm 0.9$ \\
\hline Beta-lipoproteins, $\mathrm{g} / 1$ & $1.4 \pm 0.5$ & $3.2 \pm 0.08$ \\
\hline Survival rate, $\%$ & 70 & 90 \\
\hline
\end{tabular}

\section{Conclusion}

As a result of the conducted research, biotechnological standards for growing caridean shrimp in the South of Russia were developed. The recipe has been adjusted and pilot tests have been carried out on full-scale feed for caridean shrimps. The productive effect of feed on shrimps was evaluated based on fish-biological and physiological indicators.

When growing shrimps in Russia, it is necessary to understand the technology of obtaining products based on the biology of the species and type of management. When creating a farm infrastructure, it is necessary to select a staff of highly qualified employees. The successful achievement of the team's goals will be facilitated by the use of traditions and modern achievements of shrimp farming, on the basis of which it is possible to create a technological base for growing shrimp in our country. 


\section{References}

1. The State of World Fisheries and Aquaculture 2018. Meeting the sustainable development goals FAO, http://www.fao.org/3/i9540en/i9540en.pdf

2. How to Feed the World in 2050: High-Level Expert Forum. Food and Agriculture Organization of the United Nations FAO, http://www.fao.org/fileadmin/ templates/ wsfs/docs/ expert_paper/How_to_Feed_the_World_in_2050.pdf

3. C. Costello, L. Cao, S. Gelcich, M.A. Cisneros et al., The future of food from the Sea. World Resources Institute, https://www.oceanpanel.org/future-food-sea

4. The State of World Fisheries and Aquaculture 2018. Meeting the sustainable development goals FAO, http://www.fao.org/3/i9540en/i9540en.pdf

5. T.W. Flegel, Journal of the World Aquaculture Society 50, 249-266 (2019) doi:10.1111/jwas. 12589

6. The State of World Fisheries and Aquaculture 2018. Meeting the sustainable development goals FAO, http://www.fao.org/3/i9540en/i9540en.pdf

7. L. Lagutkina, S. Ponomarev, Agricultural biology 53(2), 326-336 (2018) doi: 10.15389/agrobiology.2018.2.326

8. Giant river prawn - Feed formulation Live food, http://www.fao.org/fishery/affris/species-profiles/giant-river-prawn/feed-formulation/

9. Giant river prawn - Macrobrachium rosenbergii (De Man, 1879) http://www.fao.org/fishery/affris/species-profiles/giant-river-prawn/giant-river-prawnhome/en/

10. Giant river prawn - Nutritional deficiencies, http://www.fao.org/fishery/affris/speciesprofiles/giant-river-prawn/nutritional-deficiencies/en/

11. A.-A. Mamun, D.C. Little, M. Spargue, F.J. Murray Noakhali, Journal of Fisheries \& Livestock, 6th Global Summit on Aquaculture and Fisheries 5(2), 47 (2017) doi: 10.4172/2332-2608-C1-008

12. G.M. García-Ulloa, M.R. Pérez-Moreno, D. Rodríguez-González, M. C. Gallo-García, J.T. Ponce-Palafox, Journal of Applied Aquaculture 24(1), 8-15 (2012) doi: https://doi.org/10.1080/10454438.2012.650599

13. N.S. Calvo, S. Pietrokovsky, L.S. Greco, L. Greco, Aquaculture 304, 34-41 (2010)

14. N.S. Calvo, F. Castillo Díaz, W.C. Valenti, L.S. Greco, L. Greco, Aquaculture 319, 98-104 (2011)

15. N.S. Calvo, L. Stumpf, S. Pietrokovsky, L.S. Greco, L. Greco, Aquaculture 319, 355$362(2011)$

16. N. Cecilia Prymaczok, A. Chaulet, D. Alberto Medesani, E. Marcelo Rodríguez, Aquaculture 334-337, 176-181 (2012) 